\title{
UJI IN VIVO EFEK HEPATOPROTEKTOR EKSTRAK TERIPANG LAUT (Holothuria Scabra) DALAM VARIASI DOSIS DENGAN PARAMETER SGPT TERHADAP HEWAN UJI YANG DIINDUKSI PARASETAMOL DOSIS HEPATOTOKSIK
}

\author{
Widy Susanti Abdulkadir ${ }^{1)}$ \\ ${ }^{1)}$ Jurusan Farmasi, Universitas Negeri Gorontalo
}

\begin{abstract}
Sea cucumber sea as one of the sea animals that are efficacious as a remedy. The specialty of sea cucumber is to have the capacity to regenerate cells, so as to stimulate regenaration the cells of human tissue that had broken even decompose so that a recovered. The research is a research experiment using lab animals are in vivo. The purpose of this study to see the effects of hepatoprotektor of the provision of extracts of sea cucumber sea (Holothuria Scabra) in a variety of doses with parameters SGPT of test animals are induced paracetamol dose hepatotoxic.

This study did Pharmacology and Toxicology laboratorium from mei until agustus 2017. Methodof research using the extraction of sea cucumber sea of Holothuria Scabra the test is in vivo using mice are divided into six groups : group 1 the control of the negative (the Na. CMC $1 \%$ ), the two (extracts of sea cucumber sea $1000 \mathrm{mg} / \mathrm{kg}$ weight), a group of three (extracts of sea cucumber sea $750 \mathrm{mg} / \mathrm{kg}$ weight), a group of four (extracts of sea cucumber sea $500 \mathrm{mg} / \mathrm{kg}$ weight), a group of five control posititf (group kurkuma 2, $5 \mathrm{mg} 25 \mathrm{~g}$ of the weight of mice), a group of six control paracetamol dose of $62,5 \mathrm{mg} / 25 \mathrm{~g}$ weigth of mice). Analysis data in one way anova.

The research, produce that the negative do not differ significantly with the two $(1000 \mathrm{mg} / \mathrm{kg}$ weight) and the five groups kurkuma, $5 \mathrm{mg} / 25 \mathrm{~g}$ weight of mice). It is concluded that extracts of sea cucumber with a dose of $1000 \mathrm{mg} / \mathrm{kg}$ of weight had improved the sgpt to normal.
\end{abstract}

Key words : Extract from sea cucumber, SGPT

\begin{abstract}
ABSTRAK
Teripang laut sebagai salah satu jenis hewan laut yang berkhasiat sebagai obat. Keistimewaan teripang adalah memiliki kemampuan regenerasi sel yang tinggi, sehingga mampu merangsang regenerasi/pemulihan sel pada jaringan tubuh manusia yang telah rusak bahkan membusuk sehingga menjadi pulih kembali. Penelitian ini merupakan penelitian eksperimen yang menggunakan hewan percobaan secara in vivo. Tujuan penelitian ini untuk melihat efek hepatoprotektor dari pemberian ekstrak teripang laut (Holothuria Scabra) dalam variasi dosis dengan parameter SGPT terhadap hewan uji yang diinduksi parasetamol dosis hepatotoksik.

Penelitian ini dilaksanakan di Laboratorium Farmakologi-Toksikologi dari bulan Mei sampai Agustus 2017. Metode penelitian menggunakan hasil ekstraksi teripang laut jenis Holothuria Scabra yang di uji secara in vivo dengan menggunakan mencit yang dibagi dalam enam kelompok yaitu kelompok 1 kontrol negatif (kelompok Na. CMC 1\%), kelompok 2 (ekstrak teripang laut $1000 \mathrm{mg} / \mathrm{kg}$ bb), kelompok 3 (ekstrak teripang laut $750 \mathrm{mg} / \mathrm{kg} \mathrm{bb}$ ), kelompok 4 (ekstrak teripang laut $500 \mathrm{mg} / \mathrm{kg}$ bb), kelompok 5 kontrol posititf (kelompok kurkuma 2,5 mg/ $25 \mathrm{~g}$ bb mencit), kelompok 6 kontrol parasetamol dosis $62,5 \mathrm{mg} / 25 \mathrm{~g}$ bb mencit). Analisis data menggunakan one way anova.

Hasil Penelitian menghasilkan bahwa kelompok negatif tidak berbeda signifikan dengan kelompok 2 (1000 mg/kg BB) dan kelompok 5 kelompok kurkuma 2,5mg/25 gBB mencit). Hal ini menyimpulkan bahwa ekstrak teripang dengan dosis $1000 \mathrm{mg} / \mathrm{Kg} \mathrm{BB}$ mengalami perbaikan nilai sgpt mendekati normal.
\end{abstract}

Kata kunci: Ekstrak teripang laut, SGPT 


\section{PENDAHULUAN}

Teripang laut adalah salah satu binatang laut yang banyak terdapat di Indonesia. Di Indonesia teripang telah dimanfaatkan sejak lama, terutama oleh masyarakat disekitar pantai sebagai bahan makanan. Pasaran internasional biasanya teripang diperdagangkan dalam bentuk daging dan kulit kering (Martoyo dkk, 2006). Teripang laut memiliki kandungan "Cell growth factor" sehingga mampu merangsang regenerasi/pemulihan sel dan jaringan tubuh manusia yang telah rusak bahkan membusuk, sehingga menjadi pulih kembali. Menurut Dr. Pieter A.W Pattinama, bahwa teripang laut dapat dipakai untuk memperbaiki sel-sel yang rusak. Di alam, regenerasi sel terjadi saat teripang menghindari musuh, lingkungannya tercemar dan kenaikan suhu air. Menurut Prapto Darsono, ahli achinodermata, Pusat Penelitian dan Pengembangan Oseonologi mengatakan bahwa belum banyak yang mengelolah teripang laut menjadi obat dan hanya komoditi ekspor, karena itulah penelitian obat alami berbahan teripang dari bahari Indonesia harus dimulai dari sekarang. Menurut William Aditeja bahwa manfaat teripang laut dapat mengobati serosis hati yang dapat menyebabkan organ mengeras dan membengkak. Penelitian oleh Retno Murwani dari Univeristas Diponegoro yang telah membuktikan bahwa teripang laut mempunyai aktifitas sebagai antikanker.

Hati atau hepar adalah organ perantara antara sistem pencernaan dan darah. Salah satu fungsi hati yang penting adalah melindungi tubuh terhadap terjadinya penumpukan zat berbahaya yang masuk dari luar misalnya obat. Banyak diantara obat yang bersifat larut lemak dan tidak mudah diekskresi urin, maka sistem enzim pada mikrosom hati akan melakukan biotransformasi sedemikian rupa sehingga terbentuk metabolit yang lebih larut dalam air dan dapat dikelurgan melalui urin. Dengan faal sedemikian ini, tidak mengherankan bila hati mempunyai kemungkinan yang cukup besar pula untuk dirusak oleh obat. Hepatitis karena obat pada umumnya tidak menimbulkan kerusakan permanen, tetapi kadang-kadang dapat berlangsung lama dan fatal. Hepatotoksin adalah senyawa kimia yang memilik efek toksik pada sel hati, dengan dosis berlebihan (dosis toksik) atau pemejanan dalam jangka waktu lama senyawa bersangkutan dapat menimbulkan kerusakan hati akut maupun kronis. Obat-obatan yang lazim digunakan dapat menyebabkan efek toksik hati, sekitar 2\% dari semua kasus ikterus pada pasien yang masuk rumah sakit disebabkan karena induksi obat. Hepatotoksik parasetamol pada manusia dapat terjadi 
pada pemberian dosis tunggal 10-15 gram. Gejala pada hari pertama keracunan akut parasetamol tidak mencerminkan bahaya yang mengancam, anokreksia dan mual serta muntah diikuti dengan sakit perut terjadi 24 jam pertama dan berlangsung selama seminggu atau lebih. Gangguan fungsi hati terjadi dalam 24 jam dan setelah mencapai puncak lebih kurang 4 hari setelah pemberian parasetamol. Hepatitis kronik terjadi bila pemaparan jangka lama (sekitar 1 tahun) terhadap parasetamol (dalam batas terapi 4 gram per hari).

\section{METODE PENELITIAN}

Desain penelitian ini adalah eksperimen murni dengan menggunakan hewan percobaan secara in vivo. Penelitian ini telah lolos rekomendasi persetujuan etik yang dikeluarkan oleh fakultas kedokteran Universitas Hasanuddin dengan nomor 325/H4.8.4.5.31/PP36KOMETIK/2017.

Penelitian ini menggunakan 21 ekor mencit yang dibagi atas 7 kelompok yaitu :

1. Kelompok 1 : kontrol negatif (Na. CMC 1\%) : diberikan larutan pembawa $\mathrm{Na} \mathrm{CMC} 1 \%$ peroral 1 $\mathrm{ml} / 25$ gram $\mathrm{BB}$ mencit selama 7 hari berturut-turut. Pada hari ke 8 diambil darah dan dilakukan pembedahan hati mencit.

2. Kelompok 2 : diberikan ekstrak kering teripang laut $1000 \mathrm{mg} / \mathrm{Kg}$ $\mathrm{BB}$ atau $25 \mathrm{mg} / 25 \mathrm{~g}$ BB mencit peroral $1 \mathrm{ml} / 25$ gram BB mencit setiap hari selama 7 hari berturutturut, pada 30 menit setelah itu diberikan parasetamol dosis hepatotoksik dengan dosis 62,5 $\mathrm{mg} / 25$ gram mencit. Pada hari ke 8 diambil darah dan dilakukan pembedahan hati mencit.

3. Kelompok 3 : diberikan ekstrak kering teripang laut $750 \mathrm{mg} / \mathrm{kg} \mathrm{BB}$ atau $18,75 \mathrm{mg} / 25 \mathrm{~g}$ BB menit peroral $1 \mathrm{ml} / 25$ gram $\mathrm{BB}$ mencit setiap hari selama 7 hari berturutturut, pada 30 menit setelah itu diberikan parasetamol dosis hepatotoksik dengan dosis 62,5 mg/25 gram mencit. Pada hari ke 8 diambil darah dan dilakukan pembedahan hati mencit.

4. Kelompok 4 : diberikan ekstrak kering teripang laut $500 \mathrm{mg} / \mathrm{KgBB}$ atau $12,5 \mathrm{mg} / 25 \mathrm{~g}$ BB mencit peroral $1 \mathrm{ml} / 25$ gram BB mencit setiap hari selama 7 hari berturutturut, pada 30 menit setelah itu diberikan parasetamol dosis hepatotoksik dengan dosis 62,5 $\mathrm{mg} / 25$ gram mencit. Pada hari ke 8 diambil darah dan dilakukan pembedahan hati mencit.

5. Kelompok 5: kontrol positif kurkuma : diberikan larutan 
curcuma tablet $2,5 \mathrm{mg} / 25 \mathrm{~g} \mathrm{BB}$ mencit selama 7 hari berturut-turut, pada 30 menit setelah itu diberikan parasetamol dosis hepatotoksik $62,5 \mathrm{mg} / 25$ gram mencit. Pada hari ke 8 diambil darah dan dilakukan pembedahan hati mencit..

6. Kelompok 6 : kontrol parasetamol, diberikan larutan pembawa $\mathrm{Na}$
CMC $1 \%$ peroral $1 \mathrm{ml} / 25$ gram BB mencit selama 7 hari berturut-turut, pada 30 menit setelah itu diberikan parasetamol dosis hepatotoksik dengan dosis $62,5 \mathrm{mg} / 25$ gram mencit. Pada hari ke 8 diambil darah dan dilakukan pembedahan hati mencit.

\section{HASIL}

Tabel 1. Pengukuran kadar SGPT setelah perlakuan

\begin{tabular}{|c|c|}
\hline Kelompok & $\begin{array}{l}\text { Hasil SGPT setelah perlakuan } \\
\text { (Normal 2,1-23,8 U/1) }\end{array}$ \\
\hline \multirow[t]{3}{*}{1 Kelompok kontrol negatif (Na. CMC 1\%) } & 23 \\
\hline & 23 \\
\hline & 20 \\
\hline \multirow{3}{*}{$\begin{array}{l}2 \text { (ekstrak teripang laut dosis } 1000 \mathrm{mg} / \mathrm{Kg} \\
\mathrm{BB} \text { ) }\end{array}$} & 29 \\
\hline & 26 \\
\hline & 27 \\
\hline \multirow[t]{3}{*}{3 (ekstrak teripang laut dosis $750 \mathrm{mg} / \mathrm{Kg} \mathrm{BB}$ ) } & 41 \\
\hline & 37 \\
\hline & 35 \\
\hline \multirow[t]{3}{*}{4 (ekstrak teripang laut dosis $500 \mathrm{mg} / \mathrm{Kg} \mathrm{BB}$ ) } & 34 \\
\hline & 30 \\
\hline & 32 \\
\hline \multirow[t]{3}{*}{5 (kurkuma tablet $2,5 \mathrm{mg} / 25 \mathrm{~g} \mathrm{BB}$ ) } & 27 \\
\hline & 25 \\
\hline & 25 \\
\hline \multirow[t]{3}{*}{6 (kelompok PCT) } & 44 \\
\hline & 45 \\
\hline & 42 \\
\hline
\end{tabular}


Tabel 2. Hasil One way Anova

\begin{tabular}{|c|c|c|c|c|c|c|}
\hline \multirow[b]{3}{*}{ (I) kelompok } & \multirow[b]{3}{*}{ (J) kelompok } & \multicolumn{5}{|l|}{ Mean } \\
\hline & & Difference & Std. & & & Confidence \\
\hline & & $(\mathrm{I}-\mathrm{J})$ & Error & Sig. & Interval & \\
\hline $\begin{array}{l}\text { Kel. 1 } \\
\text { (kontrol }\end{array}$ & $\begin{array}{l}\text { kel. } 2(1000 \mathrm{mg} / \mathrm{Kg} \\
\text { BB) }\end{array}$ & $-5.33333^{*}$ & 1.57527 & .005 & -10.1451 & -.5216 \\
\hline \multirow[t]{5}{*}{ Negatif) } & $\begin{array}{lll}\mathrm{kel} .3 & (750 \quad \mathrm{mg} / \mathrm{Kg} \\
\mathrm{BB}) & & \\
\end{array}$ & $-15.66667^{*}$ & 1.57527 & .000 & -20.4784 & $\begin{array}{c}- \\
10.8549\end{array}$ \\
\hline & $\begin{array}{lll}\text { kel.4 } & (500 \quad \mathrm{mg} / \mathrm{Kg} \\
\mathrm{BB}) & & \end{array}$ & $-10.00000^{*}$ & 1.57527 & .000 & -14.8117 & -5.1883 \\
\hline & kel.5 (Kurkuma & & & & & \\
\hline & $\begin{array}{l}\text { Tablet } 2,5 \quad \mathrm{mg} / \mathrm{Kg} \\
\text { BB) }\end{array}$ & -3.66667 & 1.57527 & .038 & -8.4784 & 1.1451 \\
\hline & kel.6 (Paracetamol) & $-21.66667^{*}$ & 1.57527 & .000 & -26.4784 & $\begin{array}{l}- \\
16.8549\end{array}$ \\
\hline \multirow{6}{*}{$\begin{array}{l}\text { kel. } 2 \\
(1000 \\
\text { mg/Kg BB) }\end{array}$} & $\begin{array}{l}\text { Kel. } 1 \text { (kontrol } \\
\text { Negatif) }\end{array}$ & $5.33333^{*}$ & 1.57527 & .005 & .5216 & 10.1451 \\
\hline & $\begin{array}{lll}\text { kel.3 } & (750 \quad \mathrm{mg} / \mathrm{Kg} \\
\mathrm{BB}) & & \end{array}$ & $-10.33333^{*}$ & 1.57527 & .000 & -15.1451 & -5.5216 \\
\hline & $\begin{array}{lll}\text { kel.4 } & (500 \quad \mathrm{mg} / \mathrm{Kg} \\
\mathrm{BB}) & & \end{array}$ & -4.66667 & 1.57527 & .012 & -9.4784 & .1451 \\
\hline & kel.5 (Kurkuma & & & & & \\
\hline & $\begin{array}{l}\text { Tablet } 2,5 \quad \mathrm{mg} / \mathrm{Kg} \\
\text { BB) }\end{array}$ & 1.66667 & 1.57527 & .311 & -3.1451 & 6.4784 \\
\hline & kel.6 (Paracetamol) & $-16.33333^{*}$ & 1.57527 & .000 & -21.1451 & 11.5216 \\
\hline \multirow{4}{*}{$\begin{array}{l}\text { kel.3 } \\
(750 \mathrm{mg} / \mathrm{Kg} \\
\text { BB) }\end{array}$} & $\begin{array}{l}\text { Kel. } 1 \text { (kontrol } \\
\text { Negatif) }\end{array}$ & $15.66667^{*}$ & 1.57527 & .000 & 10.8549 & 20.4784 \\
\hline & $\begin{array}{l}\text { kel. } 2(1000 \mathrm{mg} / \mathrm{Kg} \\
\text { BB) }\end{array}$ & $10.33333^{*}$ & 1.57527 & .000 & 5.5216 & 15.1451 \\
\hline & $\begin{array}{lll}\text { kel.4 } & (500 \quad \mathrm{mg} / \mathrm{Kg} \\
\mathrm{BB}) & & \end{array}$ & $5.66667^{*}$ & 1.57527 & .004 & .8549 & 10.4784 \\
\hline & (Kurkuma & $12.00000^{*}$ & 1.57527 & .000 & 7.1883 & 16.8117 \\
\hline
\end{tabular}




\begin{tabular}{|c|c|c|c|c|c|c|}
\hline \multirow{8}{*}{$\begin{array}{ll} & \\
& \\
\mathrm{kel} .4 \quad(500 \\
\mathrm{mg} / \mathrm{Kg} \mathrm{BB})\end{array}$} & \multirow{3}{*}{$\begin{array}{l}\text { Tablet 2,5 } \mathrm{mg} / \mathrm{Kg} \\
\mathrm{BB}) \\
\text { kel.6 (Paracetamol) }\end{array}$} & \multirow{3}{*}{$-6.00000^{*}$} & \multirow{3}{*}{1.57527} & \multirow{3}{*}{.002} & \multirow{3}{*}{-10.8117} & \multirow{3}{*}{-1.1883} \\
\hline & & & & & & \\
\hline & & & & & & \\
\hline & $\begin{array}{l}\text { Kel. } \quad 1 \quad \text { (kontrol } \\
\text { Negatif) }\end{array}$ & $10.00000^{*}$ & 1.57527 & .000 & 5.1883 & 14.8117 \\
\hline & $\begin{array}{l}\text { kel. } 2(1000 \mathrm{mg} / \mathrm{Kg} \\
\text { BB) }\end{array}$ & 4.66667 & 1.57527 & .012 & -.1451 & 9.4784 \\
\hline & $\begin{array}{lll}\mathrm{kel} .3 & (750 \quad \mathrm{mg} / \mathrm{Kg} \\
\mathrm{BB}) & & \end{array}$ & $-5.66667^{*}$ & 1.57527 & .004 & -10.4784 & -.8549 \\
\hline & $\begin{array}{lrr}\text { kel.5 } & \text { (Kurkuma } \\
\text { Tablet } & 2,5 \quad \mathrm{mg} / \mathrm{Kg} \\
\text { BB) } & & \end{array}$ & $6.33333^{*}$ & 1.57527 & .002 & 1.5216 & 11.1451 \\
\hline & kel.6 (Paracetamol) & $-11.66667^{*}$ & 1.57527 & .000 & -16.4784 & -6.8549 \\
\hline $\begin{array}{l}\text { kel.5 } \\
\text { (Kurkuma }\end{array}$ & $\begin{array}{ll}\text { Kel. } \quad 1 \quad \text { (kontrol } \\
\text { Negatif) }\end{array}$ & 3.66667 & 1.57527 & .038 & -1.1451 & 8.4784 \\
\hline $\begin{array}{l}\text { Tablet 2,5 } \\
\mathrm{mg} / \mathrm{Kg} \mathrm{BB})\end{array}$ & $\begin{array}{l}\text { kel. } 2(1000 \mathrm{mg} / \mathrm{Kg} \\
\text { BB) }\end{array}$ & -1.66667 & 1.57527 & .311 & -6.4784 & 3.1451 \\
\hline & $\begin{array}{lll}\mathrm{kel} .3 & (750 \quad \mathrm{mg} / \mathrm{Kg} \\
\mathrm{BB}) & & \end{array}$ & $-12.00000^{*}$ & 1.57527 & .000 & -16.8117 & -7.1883 \\
\hline & $\begin{array}{lll}\mathrm{kel} .4 & (500 \quad \mathrm{mg} / \mathrm{Kg} \\
\mathrm{BB}) & & \end{array}$ & $-6.33333^{*}$ & 1.57527 & .002 & -11.1451 & -1.5216 \\
\hline & kel.6 (Paracetamol) & $-18.00000^{*}$ & 1.57527 & .000 & -22.8117 & $\begin{array}{l}- \\
13.1883\end{array}$ \\
\hline $\begin{array}{l}\text { kel.6 } \\
\text { (kelompok }\end{array}$ & $\begin{array}{l}\text { Kel. } \quad 1 \quad \text { (kontrol } \\
\text { Negatif) }\end{array}$ & $21.66667^{*}$ & 1.57527 & .000 & 16.8549 & 26.4784 \\
\hline Paracetamol) & $\begin{array}{l}\text { kel. } 2(1000 \mathrm{mg} / \mathrm{Kg} \\
\text { BB) }\end{array}$ & $16.33333^{*}$ & 1.57527 & .000 & 11.5216 & 21.1451 \\
\hline & $\begin{array}{lll}\mathrm{kel} .3 & (750 \quad \mathrm{mg} / \mathrm{Kg} \\
\mathrm{BB}) & & \end{array}$ & $6.00000^{*}$ & 1.57527 & .002 & 1.1883 & 10.8117 \\
\hline & $\begin{array}{l}\text { kel.4 (500 } \mathrm{mg} / \mathrm{Kg} \\
\mathrm{BB})\end{array}$ & $11.66667^{*}$ & 1.57527 & .000 & 6.8549 & 16.4784 \\
\hline & $\begin{array}{lr}\text { kel.5 } & \text { (Kurkuma } \\
\text { Tablet } & 2,5 \quad \mathrm{mg} / \mathrm{Kg}\end{array}$ & $18.00000^{*}$ & 1.57527 & .000 & 13.1883 & 22.8117 \\
\hline
\end{tabular}


BB)

*. The mean difference is significant at the 0.01 level.

\section{PEMBAHASAN}

Dalam penelitian ini dilakukan indikator kerusakan hati karena bila terjadi penelitian untuk melihat efek hepatoprotektor ekstrak teripang laut akibat pemberian parasetamol dosis hepatotoksik dengan menggunakan parameter sgpt. Penggunaan parasetamol sebagai penginduksi kerusakan hati karena masih banyak obat parasetamol ini digunakan sebagai analgesik antipiretik pada masyrakat luas terutama pada anakanak dan lanjut usia yang digunakan dalam jangka waktu panjang. Parasetamol pada normalnya akan dimetabolisme oleh hati 90\% dibiotransformasi menjadi metabolit sulfat dan glukoronat (melalui reaksi sulfat konjugasi dan glukoronat konjugasi), senyawa ini tidak toksik dan akan dieksresi melalui urin. Kira-kira $4 \%$ dari dimetabolisme oleh sitokrom P450 menjadi senyawa aktif metabolit yaitu Nasetil-p-aminobenzoquinonimin (NABQI). Secara normal NABQI didetoksifikasi oleh reaksi konjugasi dengan glutation dan selanjutnya di eksresi. Tetapi glutation yang ada dapat dihabiskan oleh sejumlah besar dari parasetamol sehingga NABQI diakumulasi dan berikatan dengan makromolekul protein sel hati secara irreversible sehingga hati mengalami nekrosis. Enzim SGPT digunakan sebagai kerusakan hati, enzim ini dilepaskan dari sitoplasma dan mitokondria sehingga kadarnya meningkat dalam darah. Transaminase adalah sekelompok enzim yang merupakan katalis dalam proses pemindahan gugus amino antara suatu asam amino dengan suatu keto, sehingga dari asam amino tersebut terbentuk satu asam 2-keto, dan dari asam keto yang sesungguhnya terbentuk satu asam amino, dalam suatu proses yang bergantung pada energy, hati mengambil asam amino tersebut. Asam-asam amino membantu hati dalam pembentukan protein. Pemeriksaan utama dalam klinik untuk pemeriksaan serum transaminase adalah untuk mengetahui adanya radang sel hati (tapi tidak menggambarkan terjadinya regenerasi sel hati). Hal ini disebabkan karena serum transaminase memiliki beberapa sifat yang menguntungkan antara lain :

1. Kenaikan kadar transaminase terjadi paling awal dalam perjalanan penyakit sebelum terjadi perubahan nilai yang lain

2. Kadar serum transaminase adalah tes yang paling akhir kembali normal dalam perjalanan penyakit 
hati

Kadar serum transaminase dapat dipakai sebagai petunjuk dari adanya kekambuhan dari suatu penyakit hati.

Tabel 1 adalah gambaran hasil pengukuran nilai sgpt dimana dari hasil tersebut dapat menggambarkan bahwa hasil pengukuran sgpt setelah perlakuan tidak semua kelompok mencit sama dengan kelompok negatif. Untuk hasil yang lebih jelas dapat dilihat pada hasil uji statistik one way anova dimana pada tabel 2 menggambarkan bahwa kelompok kontrol negatif berbeda signifikan (sig. 0,00) dengan kelompok 3 (sig. 0,00), kelompok 4 (sig. 0,00) dan kelompok 6 (sig. 0,00) yang artinya bahwa ketiga kelompok perlakuan tersebut tidak mengalami penurunan sgpt normal untuk mencit, sehingga hasil ini menggambarkan bahwa ekstrak teripang laut dengan dosis 750 $\mathrm{mg} / \mathrm{kg}$ BB dan $500 \mathrm{mg} / \mathrm{kg}$ BB belum dapat menurunkan nilai sgpr mencit. Untuk kelompok 2 (dosis ekstrak teripang 1000 $\mathrm{mg} / \mathrm{kg}$ BB) dengan nilai sig. 0,05 dan kelompok 5 (kontrol kurkuma) dengan nilai sig. 0,38 tidak berbeda signifikan dengan kelompok negatif yang artinya bahwa ke dua kelompok perlakuan tersebut mengalami penurunan nilai sgpt yang mencapai sgpt normal pada mencit yaitu kelompok 2 nilai signifikannya 0.005 (di atas 0.001) dan kelompok 5 nilai signifikannya 0.038 ( di atas 0.001) dan hasil ini menggambarkan bahwa pemberian ekstrak teripang laut pada dosis $1000 \mathrm{mg} / \mathrm{kg}$ BB sudah dapat menurunkan nilai sgpt normal pada mencit. Hasil penelitian ini juga menggambarkan bahwa tablet kurkuma memberikan hasil yang tidak signifikan (sig.0,311) dengan ekstrak teripang $1000 \mathrm{mg} / \mathrm{kg}$ BB yang artinya penurunan nilai sgpt antara ke dua kelompok tersebut tidak mengalami perbedaan yang nyata dimana ke dua kelompok tersebut sama-sama memberikan gambaran penurunan spgt yang sama dengan sgpt normal mencit. Sehingga tablet kurkuma yang telah banyak digunakan masyarakat sebagai hepatoprotektor sebanding dengan ekstrak teripang $1000 \mathrm{mg} / \mathrm{kg} \mathrm{BB}$ dan kedua kelompok tersebut memberikan hasil yang sama dengan kontrol negatif.

\section{KESIMPULAN}

Hasil penelitian menggambarkan bahwa ekstrak teripang dengan dosis 1000 $\mathrm{mg} / \mathrm{kg}$ BB mengalami penurunan nilai sgpt yang sebanding dengan kontrol negatif (kelompok Na.CMC) dan kontrol positif (Kelompok kurkuma).

\section{UCAPAN TERIMA KASIH}

1. Terima kasih kepada Kemenristek Dikti atas dukungan dananya

2. Terima kasih untuk Kepala Dinas Perikanan Propinsi Gorontalo 
PERTIMBANGAN MASALAH ETIK

Pertimbangan masalah etik sudah dilakukan oleh Fakultas Kedokteran Universitas Hasanuddin dengan no. 325/H4.8.4.5.31/PP36-KOMETIK/2017.

\section{DAFTAR PUSTAKA}

Farrouk Abd Hamid Ghous and B.H Ridzwan. New species isolated from Malaysian sea cucumber with optimized secreted antibacterial activity. American J. of Biocherm and Biotech. 2007; 3(2):60-65

Zancan P. and P.A Mourao. Venous and arterial thrombosis in rat models: dissociation of the antitrombotic effect of glycosaminoglycans. Blood Coagul. Fibrinolysis. 2004; 15:45-54 Hatakeyama, T.,N. Matsuo, K. Shiba, S Nishinohara, N. Yamasaki, H.Sugawara and H. Aoyagi. Amino acid sequence and carbohydratebinding analysis of the N-acetyl-Dgalactosamine-specific C-type lectin, CEL-I, from the Holothuridae, Cucumaria echinata. Biosci. Biotechnol. Biochem. 2002; 66:157163

Afiyatullov, S. S.,A.I. Kalinovsky, T.A Kuznetsova, V.V. Isakov, M.V. Pivkin, P.S Dmitrenok and G.B Elyakov. New diterpene glycosides of the fungus Acremonium striatisporum isolated from a sea cucumber. J.Nat.Prad. 2002; 65: 6414

Widysusanti A. Tesis. Efek Pemberian Suspensi teripang Pasir terhadap Hepatotoksik Parasetamol pada Mencit secara Histopatologi, Makassar: Unhas; 2009

Sara, B.,A. Farooq and S. Nazamid. HighValue Components and Bioactives from Sea Cucumber for Functional Foods-A Review. Journal of Marine Drugs. 2011; 9:1761-1805 